\title{
PERAN KEPEMIMPINAN DALAM MENINGKATKAN KINERJA PEGAWAI PADA DINAS KELAUTAN DAN PERIKANAN KABUPATEN BIAK NUMFOR
}

\author{
Hermanu Iriawan \\ Program Studi Magister Ilmu Administrasi Publik, IISIP Yapis Biak \\ Email: karsipapua10@gmail.com
}

Diterima: 20 Maret 2020; Direvisi: 15 Juli 2020; dipublikasikan: 28 Agustus 2020

\begin{abstract}
ABSTRAK
Kepemimpinan merupakan usaha seseorang untuk mempengaruhi orang lain. Penelitian ini bertujuan untuk mengetahui peran kepemimpinan dalam meningkatkan kinerja pegawai pada Dinas Kelautan dan Perikanan Kabupaten Biak Numfor. Penelitian ini menggunakan pendekatan deskriptif kualitatif. Tehnik pengumpulan data dengan menggunakan wawancara, observasi, dan dokumentasi. Hasil penelitian menunjukkan bahwa Kemampuan pimpinan dalam meningkatkan kinerja pegawai sudah menunjukkan hasil yang baik meskipun pegawai masih membutuhkan perhatian, motivasi, serta pengawasan dari seorang pimpinan.
\end{abstract}

Kata Kunci: Peran, Kepemimpinan, Kinerja.

\begin{abstract}
Leadership is an attempt by someone to influence others. This study aims to determine the role of leadership in improving employee performance at the Department of Maritime Affairs and Fisheries of Biak Numfor Regency. This study uses a qualitative descriptive approach, data collection techniques using interviews, observation and documentation, the results of the study indicate that the ability of leaders to improve employee performance has shown good results even though employees still need attention, motivation and supervision from a leader.
\end{abstract}

Keywords: Role, Leadership, Performance

\section{PENDAHULUAN}

Dinas Kelautan dan Perikanan di Kabupaten Biak Numfor merupakan suatu instansi yang merupakan salah satu Lembaga Teknis Daerah Kabupaten Biak Numfor yang mempunyai tugas pokok membantu Bupati dalam penyelenggaraan pemerintah daerah, dimana tugas penyelenggaraan pemerintah daerah dan pelayanan kepada masyarakat merupakan tantangan bagi Dinas Kelautan dan Perikanan Kabupaten Biak Numfor. Sebagaimana pegawai negeri pada umumnya, pegawai negeri yang ada di lingkungan Dinas Kelautan dan Perikanan juga mengemban tugas-tugas, yaitu 
memberikan pelayanan yang baik pada masyarakat yang pelaksanaannya menuntut adanya motivasi dari pemimpin bagi para pelaksanaannya.

Nilai-nilai budaya di lingkungan Dinas Kelautan dan Perikanan masih banyak yang perlu diperbaiki dan dikembangkan. Hal ini memerlukan proses dan memakan waktu yang relatif lama. Perilaku para pegawai organisasi merupakan pencerminan nilai-nilai budaya yang dianut oleh suatu organisasi. Membangun asumsi dasar, keyakinan dan norma-norma, seperti sopan santun, cara berbicara, cara memberikan pelayanan kepada masyarakat, membangun kebersamaan, penataan ruang kerja dan lain-lain merupakan tuntutan sekaligus tantangan bagi seorang pemimpin untuk mewujudkannya. Namun, di sisi lain opini sebagian besar masyarakat menyatakan bahwa masih banyak pegawai pemerintah terkesan bukan sebagai pelayan masyarakat, tetapi sebagai orang yang minta dilayani. Sejalan dengan meningkatnya tuntutan akan hak-hak yang harus diterima oleh masyarakat berupa pelayanan, kinerja pegawai semakin dituntut untuk lebih maksimal dalam pelayanan. Hal tersebut merupakan konsekuensi dari seorang pemimpin dalam menciptakan suasana yang kondusif, sehingga meningkatkan motivasi kerja pegawai dalam pelayanannya.

Untuk meningkatkan kinerja pegawai diperlukan peran kepala dinas selaku pemimpin dan pembina dalam organisasi, sehingga dengan begitu pegawai akan semakin mampu dan mudah dalam menjalankan tugasnya, sehingga tujuan dari organisasi akan tercapai secara efektif dan efisien. Kinerja pegawai pada Dinas Kelautan dan Perikanan di Kabupaten Biak Numfor salah satunya tergantung pada kepemimpinan. Faktor kepemimpinan memegang peranan penting dalam pelaksanaan kinerja pegawai untuk menciptakan semangat kerja yang tinggi. Dalam pelaksanaan Kepemimpinan Dinas Kelautan dan Perikanan, diharapkan dapat meningkatkan semangat kerja dan supaya mempersiapkan pegawai yang profesional di bidangnya. Terlaksananya tugas-tugas tertentu dengan berhasil merupakan tanggung jawab pimpinan dan biasanya dinilai atas dasar pimpinan dapat mengatur tugas-tugas untuk diselesaikan. Organisasi mencapai tujuan dan memenuhi kebutuhan bawahannya tergantung pada baik tidaknya kepemimpinan yang dilaksanakan. Apabila kepemimpinannya kurang baik maka organisasi atau instansi tersebut tidak akan berhasil mencapai tujuan apalagi ingin meningkatkan motivasi kerja dengan baik dan benar.

Oleh sebab itu, faktor kepemimpinan merupakan faktor yang menentukan tercapainya tujuan suatu organisasi tergantung kepemimpinan yang dijalankan oleh seorang pimpinan. Kedudukan seorang pimpinan dalam suatu organisasi merupakan figur yang unik untuk dipelajari dan sangat menarik untuk diteliti terutama dalam keberhasilannya memimpin suatu organisasi dalam mencapai tujuan yang telah ditetapkan. Nilai-nilai budaya di lingkungan Dinas Kelautan dan Perikanan masih banyak yang perlu diperbaiki dan dikembangkan. Hal ini memerlukan proses dan memakan waktu yang relatif lama.

Motivasi dari pemimpin dapat membangkitkan semangat kerja pegawai untuk bekerja lebih baik, sehingga seorang pegawai yang memiliki motivasi yang tinggi akan memengaruhi kepuasan kerja menjadi lebih tinggi. Peranan motivasi dalam meningkatkan kerja karyawan sangat penting, antara lain agar motivasi yang diberikan dalam bentuk bimbingan maupun pelatihan dapat menggerakkan setiap karyawan untuk bisa bekerja mencapai kinerja yang diha- rapkan. Oleh karena itu, menjadi tugas utama pimpinan organisasi atau pemerintah daerah untuk mengetahui pengaruhpengaruh yang dapat mendorong orang-orang yang dipimpinnya agar mau berjalan bersama untuk mencapai tujuan yang telah ditetapkan sebelumnya (Harlie, 2012).

Dengan adanya pegawai yang termotivasi, maka dapat lebih mudah mencapai kinerja yang diharapkan dalam organisasi, sehingga kepuasan kerja lebih mudah dicapai. Untuk menciptakan organisasi yang memiliki daya saing yang tinggi, organisasi sebaiknya dikelolah oleh orang-orang yang memiliki gaya kepemimpinan yang cocok atas setiap perubahan situasi yang terjadi pada 
organisasi. Ini berarti pimpinan selain memiliki kemampuan manajerial yang tinggi juga harus bisa membaca situasi yang berkembang. Agar tujuan organisasi yang dijalankan dengan baik dan dapat mencapai hasil yang optimal, seorang pemimpin harus didukung oleh pegawai atau bawahan yang memiliki kualitas kinerja yang baik, sehingga yang direncanakan oleh organisasi dapat terwujud dengan maksimal pula. Begitupun sebaliknya jika hal itu tidak dilaksanakan akan memperoleh hasil kinerja yang tidak maksimal juga. Sumber daya manusia merupakan tokoh sentral dalam sebuah organisasi. Agar aktivitas manajemen berjalan dengan baik, organisasi harus memiliki pegawai yang berpengetahuan dan berketerampilan tinggi serta usaha untuk mengelola organisasi seoptimal mungkin, sehingga kinerja pegawai meningkat (Maria, 2013). Lebih lanjut kepemimpinan dibutuhkan manusia karena adanya suatu keterbatasan dan kelebihan-kelebihan tertentu pada manusia. Di satu pihak, manusia terbatas kemampuannya untuk memimpin, di pihak lain ada orang yang mempunyai kelebihan kemampuan untuk memimpin disinilah timbulnya kebutuhan akan pemimpin dan kepemimpinan (Edyanto, 2018).

Peran adalah suatu sikap, tindakan atau perilaku yang diharapkan oleh banyak orang atau sekelompok orang terhadap seseorang yang memiliki status atau kedudukan tertentu (Rumlus, Lumolos, \& Mantiri, 2014). Kepemimpinan merupakan usaha seseorang untuk mempengaruhi orang lain. Dengan demikian, pemimpin tentunya harus mempunyai karakteristik khusus yang nantinya akan sangat berpengaruh terhadap gaya kepemimpinan seseorang (Edyanto, 2018) Betapa pentingnya pemimpin dan kepemimpinan dalam suatu kelompok jika terjadi suatu konflik atau perselisihan di antara orang-orang dalam kelompok, orang-orang mencari cara pemecahan supaya terjamin keteraturan dan dapat ditaati bersama. Kinerja aparat pemerintahan merupakan suatu sistem yang bertujuan untuk membantu atasan dalam menilai pencapaian suatu strategi melalui alat ukur finansial dan nonfinansial, kinerja dapat diukur dari kemampuan kinerja dalam mencapai target yang dianggarkan (Restu Agusti, 2012). Menurut Ivonne (2013) kinerja adalah kuantitas atau kualitas hasil kerja individu atau sekelompok di dalam organisasi dalam melaksanakan tugas pokok dan fungsi yang berpedoman pada norma, standar oprasional prosedur, kiteria, dan ukuran yang telah ditetapkan atau yang berlaku dalam organisasi. Kinerja adalah merujuk pada tingkat pencapaian atau prestasi dari perusahaan dalam periode waktu tertentu (Rahayu Puji Suci, 2009). Kinerja bukan menyangkut karakteristik pribadi yang ditunjukkan oleh seseorang melalui hasil kerja yang telah dan akan dilakukan seseorang. Kinerja dapat pula diartikan sebagai kesuksesan individu dalam melakukan pekerjaannya (Kurnia Riyantini dan Agus Triyono, 2016).

Berdasarkan pengamatan peneliti, peran kepemimpinan yang dilaksanakan pada Dinas Kelautan dan Perikanan di Kabupaten Biak Numfor dianggap belum maksimal sesuai dengan harapan yang diinginkan oleh pemerintah maupun masyarakat, khususnya terhadap kinerja pegawai. Perhatian, motivasi, serta pengawasan dari seorang pimpinan yang masih minim membuat kinerja pegawai kurang maksimal. Padahal dalam meningkatkan bawahan atau pegawai sangat membutuhkan sosok pimpinan yang berkualitas dan professional.Permasalahan-permasalahan yang terkait rendahnya kinerja pegawai dan merupakan imbas dari peran kepemimpinan yang kurang maksimal antara lain disiplin kerja pegawai masih kurang maksimal, kadang pegawai tidak tepat waktu masuk dan sering cepat pulang kerja, dalam menyelesaikan suatu pekerjaan atau tugas kurang efektif dan efisien, pembagian kerja tidak merata dan kurang sesuai dengan fungsi dan tugas dari pegawai, keputusan pimpinan kurang konsisten. Di sisi lain ada pegawai yang mempunyai kinerja yang baik dan maksimal, kurang diperhatikan oleh pimpinan, kepemimpinan seperti inilah yang dianggap kurang maksimal dan untuk mencapai tujuan organisasi yang lebih baik, perlu dilakukan suatu perubahan demi tercapainya tujuan organisasi. 


\section{METODE}

Penelitian ini menggunakan pendekatan kualitatif, yaitu deskriptif analisis. Dalam penelitian deskriptif hanya menekankan, tidak berhak mengontrol keadaan, pada waktu dilakukan penelitian hanya bisa mengukur apa yang ada. Pelaksanaan metode penelitian deskriptif tidak terbatas hanya sampai pada pengumpulan dan penyusunan data, tetapi meliputi analisis dan interprestasi tentang arti data tersebut. Selain itu, semua yang dikumpulkan berkemungkinan menjadi kunci terhadap yang diteliti. Teknik pengumpulan data yang digunakan dalam penelitian ini adalah wawancara, observasi, dan dokumentasi. Di dalam rancangan penelitian kualitatif, fokus kajian penelitian dan atau pokok soal yang hendak diteliti mengandung penjelasan mengenai dimensi-dimensi yang menjadi pusat perhatian yang kelak dibahas secara mendalam. Penelitian ini difokuskan pada peran kepemimpinan dalam meningkatkan kinerja pegawai pada Dinas Kelautan dan Perikanan di Kabupaten Biak Numfor.

\section{HASIL DAN PEMBAHASAN}

\section{Peran Kepemimpinan dalam Meningkatkan Kinerja Pegawai}

Peran seorang pemimpin sangat penting dalam meningkatkan kinerja pegawai dalam suatu organisasi atau perusahaan. Segala sesuatu yang berkaitan dengan kemajuan dan kesuksesan suatu organisasi hanya dapat terlaksana oleh adanya campur tangan ataupun buah pikiran seorang pimpinan. Peran seorang pemimpin dapat diketahui melalui keberhasilannya dalam mencapai tujuan organisasi.

Hasil wawancara langsung yang dilakukan kepada beberapa pegawai di Dinas Kelautan dan Perikanan di Kabupaten Biak Numfor, antara lain hasil wawancara yang di lakukan dengan informan inisial IS, mengemukakan bahwa:

“........Pimpinan selalu memberikan beban kerja sesuai dengan Tupoksi masing-masing pegawai yang ada di lingkungan Dinas Kelautan dan Perikanan di Kabupaten Biak Numfor. Hal itu tidak dianggap sebagai suatu beban yang berat. Kami pegawai sangat tidak merasa terpaksa dalam menjalankan perintah atasan karena sebagai PNS (Pegawai Negeri Sipil) sudah menjadi kewajiban untuk melaksanakan tugas dan tanggung jawab yang dibiayai oleh Negara".

Informasi yang sama diperoleh juga dari hasil wawancara langsung dengan informan inisial IL yang dilakukan pada tanggal yang sama mengatakan bahwa :

“.......Pemimpin atasan kami kadang memberikan kesempatan kepada kami untuk menyampaikan pendapat, tetapi hanya sesaat saja selanjutnya dalam hal-hal tertentu tidak diberikan kesempatan, perintah pimpinan tidak menjadi beban berat bagi kami pegawai, karena yang namanya perintah pimpinan harus dilaksanakan. Kami juga tidak merasa tertekan dan terpaksa karena sebagai bawahan harus melaksanakan perintah atasan".

Demikian halnya dengan informan yang diperoleh lewat wawancara langsung yang dilakukan dengan informan inisial TN, yang mengemukakan bahwa:

“........Pimpinan selalu melakukan suatu tindakan atau pekerjaan selalu dikerjakan bersamasama dengan semua staf. Dalam pengambilan keputusan atau rapat pimpinan selalu memberikan kesempatan kepada bawahannya untuk mengeluarkan pendapat. Perintah atasan tidak menjadi beban buat kami, dan semua dikerjakan secara bersama-sama. Jadi kami tidak merasa terpaksa dalam menjalankan perintahnya. Pimpinan kami tidak bertindak atas 
keinginan atau kehendaknya sendiri, namun dilakukan secara bersama dan transparan. Dalam rapat atau mengambil suatu keputusan pimpinan juga memberikan kami kesempatan untuk mengeluarkan pendapat".

Dari keseluruhan pernyataan-pernyataan di atas dapat dikatakan bahwa peran kepemimpinan dalam meningkatkan kinerja pegawai pada Dinas Kelautan dan Perikanan di Kabupaten Biak Numfor belum maksimal. Hal itu dapat diketahui dengan informasi yang berbeda dari informan yang mengatakan bahwa pimpinan memang bertanggung jawab namun tidak bersikap adil dan kurang kerja sama. Selain itu, pimpinan juga kurang konsisten dengan keputusan yang telah disepakati bersama. Namun, di sisi lain sebagian besar informan memberikan jawaban yang positif, yakni bersikap adil, partisipatif, dan membangun kerja sama yang baik dengan bawahan guna mencapai tujuan organisasi. Hal ini sama halnya sebagai wirausaha dalam meningkatkan pangsa pasar adalah dengan meningkatkan keterampilan manajerial dengan meningkatkan kapasitas, etos kerja, dan kinerja lembaga dan staf pemerintah daerah Semarang, dan meningkatkan partisipasi masyarakat dalam perencanaan, implementasi, dan pemantauan pengembangan UKM (Ariwibowo, 2018).

\section{Upaya Meningkatkan Kinerja Pegawai}

1. Pengarahan

Sebagai seorang pemimpin, maka dalam rangka melaksanakan perannya selaku pimpinan, hendaknya memberikan petunjuk-petunjuk kepada bawahannya. Disamping itu, pengarahanpengarahan akan lebih meningkatkan komunikasi antara atasan dan bawahan, sehingga dapat dilakukan interaksi guna mengkondisikan agar visi dan persepsi serta wawasan menjadi sama.

2. Pengembangan

Pengembangan disini adalah kesempatan yang diberikan oleh pimpinan untuk meningkatkan potensi yang dimiliki pegawai pada Dinas Kelautan dan Perikanan. Pengembangan diberikan dalam bentuk pendidikan dan pelatihan-pelatihan bagi setiap pegawai yang memiliki kapabilitas.

3. Hubungan Kemanusiaan

Kepala Dinas selaku pimpinan tertinggi di Dinas Kelautan dan Perikanan, dalam melaksanakan tugas pelayanan kepada masyarakat dituntut untuk membina hubungan yang baik dengan para pegawai/bawahan. Salah satu cara yang ditempuh adalah dengan menciptakan komunikasi yang baik antara atasan dengan bawahan, maupun antara sesama bawahan.

\section{SIMPULAN}

Peran kepemimpinan kepala Dinas Kelautan dan Perikanan dalam menumbuhkan pemahaman dan kesadaran para pegawainya sudah bagus hanya masih kurang tegas kepada pegawainya, karena ketegasan seorang pemimpin menjadi salah satu faktor utama dalam hal kepemimpinan. Disamping itu, kemampuan pimpinan dalam meningkatkan kinerja pegawai sudah menunjukkan hasil yang baik, meskipun masih terlihat adanya pekerjaan yang dilaksanakan pegawai atau bawahan ada yang tidak sesuai dengan yang diperintahkan oleh atasan. 


\section{Sosio e-kons}

Volume 12, No. 2, Agustus 2020, pp. 150-155

e-ISSN: 2502-5449

p-ISSN: 2085-2266

DOI : $10.30998 /$ sosioekons.v12i02.6232

\section{DAFTAR RUJUKAN}

Ariwibowo, P. (2018). The Strategy Of Empowerment Small And Medium Enterprises In The Effort For Increasing Revenue And Market. Jurnal Ilmiah Econosains, 16(1), 35 - 47. https://doi.org/10.21009/econosains. 0161.04.

Edyanto, K. (2018). Leadership Bupati Dalam Pembangunan Di Kabupaten Tambrauw (Studi Kepemimpinan Bupati Tambrauw). Sosio E-Kons, 10(2), 143-149.

Harlie, M. (2012). Pengaruh Disiplin Kerja,Motivasi dan Pengembangan Karier terhadap Kinerja Pegawai Negeri Sipil pada Pemerintah Kabupaten Tabalong di Tanjung Kalimantan Selatan. Jurnal Aplikasi Manajemen, 10(4), 860-867.

Ivonne A.S. Sajangbati. (2013). Motivasi, Disiplin, Dan Kepuasan Pengaruhnya Terhadap Kinerja Pegawai PT. POS Indonesia (PERSERO) Cabang Bitung. Jurnal EMBA, 1(4), 667-678.

Kurnia Riyantini dan Agus Triyono. (2016). Pengaruh Kepuasan Komunikasi Organisasi Terhadap Kinerja Pegawai Di Sekretariat DPRD Kota Singkawang. Informasi, 46(2).

Maria, A. (2013). Pengaruh Gaya Kepemimpinan, Pengaruh Sumber Daya Manusia dan Disiplin Kerja terhadap Kinerja Pegawai Sekretariat Dewan Perwakilan Rakyat Daerah Provinsi Sulawesi Tengah. Katalogis, 1(1), 95-104.

Rahayu Puji Suci. (2009). Peningkatan Kinerja Melalui Orientasi Kewirausahaan , Kemampuan Manajemen , dan Strategi Bisnis. Jurnal Manajemen Dan Kewirausahaan, 11(1), 46-58.

Restu Agusti. (2012). Pengaruh Partisipasi Penyusunan Anggaran Terhadap Kinerja Aparatur Pemerintah Daerah Dengan Dimoderasi Oleh Variabel Desentralisasi Dan Budaya Organisasi ( Studi Kasus Pada Pemerintah Kabupaten Bengkalis). Ekonomi, 20(3), 1-15.

Rumlus, R., Lumolos, J., \& Mantiri, M. (2014). Peran Pemerintah Desa Dalam Pemberdayaan Masyarakat (Suatu Studi Pada Kelompok Nelayan di Desa Trikora Kecamatan Kaimana Kabupaten Kaimana Provinsi Papua Barat). 